\title{
PERAN KECENDERUNGAN KEPRIBADIAN DALAM PEMILIHAN STRATEGI COPING
}

\author{
lin Tri Rahayu \\ Fakultas Psikologi \\ Universitas Islam Negeri (UIN) Maulana Malik Ibrahim Malang \\ Jl. Gajayana 50 Malang Telp. 0341-558916
}

\begin{abstract}
Abstrak - Strategi coping menunjuk pada berbagai upaya, baik mental maupun perilaku, untuk menguasai, mentoleransi, mengurangi, atau minimalisasikan suatu situasi atau kejadian yang penuh tekanan. Proses coping yang dilakukan individu selain tidak bisa lepas dari situasi yang menimbulkan stres juga dipengaruhi oleh faktor yang ada dalam diri individu. Oleh karena itu kemampuan dan kapasitas yang dimiliki individu merupakan faktor yang penting untuk diperhatikan ketika melakukan studi tentang proses coping (Parkes, 1986). Salah satu kapasitas dalam diri individu yang mempengaruhi coping adalah aspek kepribadian. Pada waktu dihadapkan pada hal, peristiwa, orang atau keadaan yang dapat mengakibatkan stres individu memikirkan kemungkinan-kemungkinan yang dapat menimpa individu tersebut. Pertama, individu menyimpulkan bahwa hal yang mendatangkan stres itu tidak berarti apa-apa bagi kesejahteraan hidupnya. Kedua, individu sampai pada kesimpulan bahwa persitiwa yang dapat mendatangkan stres itu ternyata baik dan mendatangkan keuntungan bagi dirinya. Ketiga, individu mau tidak mau harus menerima bahwa keadaan yang dihadapi memang mendatangkan stres (Hardjana, 1994). Bersamaan dengan proses penilaian tersebut individu juga menilai dan mempertimbangkan sumber daya yang ada dalam dirinya untuk mengatasi stres.
\end{abstract}

Kata Kunci: Kepribadian, Strategi Coping, Stressi

PSIKOISLAMIKA. Jurnal Psikologi Islam (JPI) copyright @ 2013 Laboratorium Penelitian, Kajian Psikologi Islam dan Penerbitan. Volume 10. Nomor 2, Tahun 2013

\section{PENDAHULUAN}

Stres merupakan hal yang melekat pada kehidupan. Siapa saja dalam bentuk tertentu, dalam kadar berat ringan yang berbeda dan dalam jangka panjang-pendek yang tidak sama, pernah atau akan mengalaminya. Tak seorang pun bisa terhindar daripadanya. Bayi bisa terkena stres, balita bisa kedatangan stres, remaja tidak bisa luput daripadanya, kaum muda tak mungkin terhindar. Orang dewasa pasti mengalami, kelompok lansia apalagi. Sebagai bagian dan pengalaman hidup, stres merupakan hal rumit, kompleks. Karena itu stres dapat dilihat dari sudut pandang yang berbeda. Dalam peristiwa stres sekurang-kurangnya ada tiga hal yang saling mengkait, yaitu hal, peristiwa, orang, keadaan yang menjadi sumber stres (stressor), orang yang mengalami stres (the stressed) dan hubungan antara orang yang terkena stres dengan hal yang menyebabkan stres.
Dalam beberapa dekade terakhir perhatian yang khusus telah diberikan kepada bagaimana indidividu dapat menangani tekanan (stress) dengan baik, karena tekanan bisa mempengaruhi setiap segi dalam mengejar kesejahteraan hidup. Bagaimana individu menangani atau mengurangi tekanan disebut dengan coping.

Strategi coping menunjuk pada berbagai upaya, baik mental maupun perilaku, untuk menguasai, mentoleransi, mengurangi, atau minimalisasikan suatu situasi atau kejadian yang penuh tekanan. Dengan perkataan lain strategi coping merupakan suatu proses dimana individu berusaha untuk menanggani dan menguasai situasi stres yang menekan akibat dari masalah yang sedang dihadapinya dengan cara melakukan perubahan kognitif maupun perilaku guna memperoleh rasa aman dalam dirinya (Duhachek \& lacobucci, 2005). 
Proses coping yang dilakukan individu selain tidak bisa lepas dari situasi yang menimbulkan stres juga dipengaruhi oleh faktor yang ada dalam diri individu. Oleh karena itu kemampuan dan kapasitas yang dimiliki individu merupakan faktor yang penting untuk diperhatikan ketika melakukan studi tentang proses coping (Parkes, 1986). Salah satu kapasitas dalam diri individu yang mempengaruhi coping adalah aspek kepribadian. Beberapa penelitian dilakukan dalam rangka mengetahui hubungan antara strategi coping dan aspek kepribadian dalam diri individu. Seperti dilakukannya penelitian tentang korelasi antara individu dengan Perilaku Tipe A dengan pola coping dan daya tahan (Pittner \& Houston, 1980; Vickers, Hervig, Rahe\& Rosenman, 1981, dalam Parkes, 1986). Korelasi antara internal kontrol dengan problem oriented coping (Anderson, 1977; Parkes, 1984; dalam Parkes, 1986), korelasi antara trait anxiety dengan maladaptive coping (Parasuraman \& Cleek, 1984; dalam Parkes, 1986). Korelasi antara keecenderungan optimisme dengan cara individu melakukan coping terhadap stres ( Scheier \& Carver, 1985; Scheier, Weintraub \& Carver, 1986; dalam Lee, Ashford, \& Jamieson, 1993). Penelitian yang lebih luas tentang karakteristik kepribadian dengan coping juga dilakukan oleh Fleishman pada tahun 1978 (Parkes, 1986). Studi yang dilakukan oleh McCrae dan Costa di tahun 1986, menunjukkan pengaruh neuroticism dan extraversi terhadap mekanisme koping (Parkes, 1986).

\section{KERANGKA KERJA TEORITIK}

Menurut pengertian etimologis atau bahasa, kata kepribadian atau personality dalam bahasa inggris atau persona dalam bahasa Latin yang artinya kedok atau topeng yang maksudnya untuk menggambarkan perilaku, watak atau kepribadian seseorang. Allport (dalam Suryabrata, 2000) merumuskan kepribadian sebagai sesuatu yang terdapat dalam diri individu yang membimbing dan memberi arahan kepada seluruh tingkah laku individu yang bersangkutan. Tepatnya kepribadian adalah sesuatu organisasi yang dinamis dari sistem psikofisik yang menentukan caranya yang khas dalam menyesuaikan diri terhadap lingkungan (Allport, 1951). Cattle (dalam Hall \& Lindzey, 1993) berpendapat bahwa kepribadian adalah sesuatu yang memungkinkan prediksi tentang apa yang dikerjakan seseorang dalam situasi tertentu.

\section{Proses Pembentukan Kepribadian}

Manusia dilahirkan sudah diberi potensi-potensi kepribadian menurut sifat-sifat kepribadian yang unik baik secara psikologis maupun secara fisik. Dan sejalan dengan perkembangannya manusia mengalami suatu proses dimana proses ini akan mempengaruhi pembentukan kepribadiannya, apalagi dengan adanya faktor individual differences yaitu yaitu faktor-faktor yang menyebabkan adanya perbedaan antara individu satu dengan yang lainnya.

Menurut Thomas dan Chess (1977, dalam Atkinson, 1999) bahwa kepribadian individu sudah tampak ketika individu baru dilahirkan dan pada bayi yang baru lahir perbedaan karakteristik seperti keaktifan, rentang perhatian, kemampuan untuk menyesuaikan diri terhadap perubahan lingkungan dan suasana hati dapat diamati segera setelah kelahiran. Pembentukan kepribadian individu dipengaruhi oleh faktor biologis, faktor pengalaman umum dan faktor pengalaman unik (Atkinson, 1999). Pada faktor biologis, pembentukan kepribadian individu dapat diamati setelah kelahiran dimana individu sudah memperlihatkan perbedaan suasana hati dan tingkat keaktifannya yang menunjukkan bahwa adanya pengaruh faktor genetik. Pendapat senada diungkapkan oleh Scoupenhour yang mengatakan bahwa faktor pembawaan lebih kuat dari faktor luar. Aliran in didukung oleh aliran naturalis yang ditokohi oleh J.J Rousseau (dalam Agus dkk, 1986). Pada faktor pengalaman umum, semua keluarga dalam suatu budaya mempunyai kebiasaan, dan nilai umum. Dari keyakinan dan kebiasaan yang terdapat di dalam keluarga selama fase perkembangannya anak mulai belajar untuk melakukan perilaku dengan cara yang diharapkan oleh lingkungan sekitarnya. Dengan demikian dapat dikatakan bahwa lingkungan dapat menentukan kepribadian individu. Hal ini diungkapkan oleh John Locke tokoh aliran empirisme (Agus dkk, 1986) bahwa faktor lingkungan yang banyak mempengaruhi dalam pembentukan kepribadian seseorang, baru akan berisi bila ia menerima sesuatu dari luar lewat alat inderanya, pendapat tersebut lebih dikenal dengan teori tabularasa. Aliran ini disokong oleh J.F Herbalt tokoh aliran Asosiasi (Agus dkk, 1986) yang menyatakan bahwa jiwa manusia itu sejak lahir masih kosong, baru akan diisi sesuatu bila alat inderanya telah menangkap sesuatu. Meskipun lingkungan sekitar dapat berpengaruh terhadap kepribadian dan menentukan beberapa kemiripan kepribadian, akan tetapi kepribadian seseorang tidak akan pernah dapat diprediksi sepenuhnya dari pengetahuan kelompok dimana orang ini dibesarkan, karena dampak budaya terhadap individu tidak sama disampaikan oleh orang tua dan orang lain 
yang mungkin tidak memiliki kesamaan nilai dan individu mempunyai beberapa pengalaman yang bersifat unik.

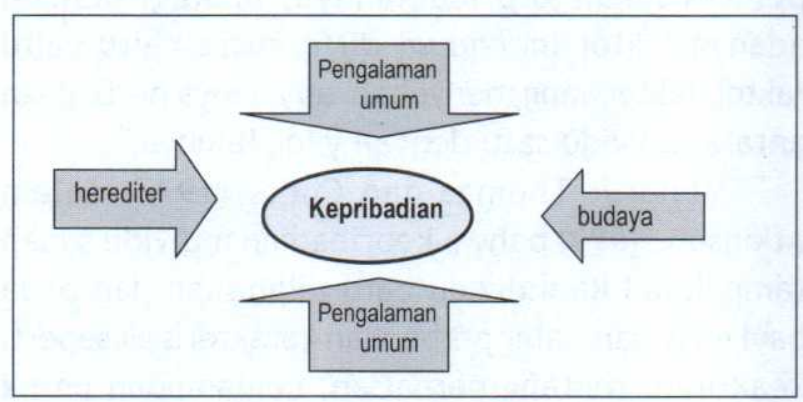

Gambar 1.1

Prose Pembentukan Kepribadian

Faktor pengalaman unik, sejalan dengan proses perkembangan dan dengan semakin bertambahnya usia, individu semakin banyak belajar dari lingkungan, dari pengalaman yang diperolehnya melalui proses belajar tersebut akan berpengaruh terhadap pola pikir dan tingkah laku individu itu nantinya. Sedangkan Cattle (dalam Hall \& Linszey, 1993) berpendapat bahwa pembentukan kepribadian individu dipengaruhi oleh sifat atau trait. Menurut Cattle (dalam Hall \& Lindzey, 1993) proses perkembangan kepribadian meliputi dua hal yaitu, pertama, Prinsip-prinsip belejar. Dimana perubahan dan perkembangan kepribadian individu diperoleh melalui prinsip-prinsip belajar dari serangkaian peristiwa yang dilalui individu sebagai akibat dari bentuk penyesuaian antara herediter (sebagai faktor endogen) dan lingkungan sebagai faktor (eksogen). Kedua, peranan faktor-faktor sosio kultural. Menurut Cattle kehidupan sosial manusia berpengaruh terhadap perkembangan kepribadian individu, seperti keluarga, sekolah, kelonpok teman sebaya, agama, partai politik dan sebagainya.

\section{Lima Faktor Kecenderungan Kepribadian}

Ada lima faktor kecenderungan kepribadian yang dikemukakan oleh $\mathrm{McC}$ rae, yaitu:

1) Neuroticism $(\mathrm{N})$

Mengukur penyesuaian dan ketidakstabilan emosi. Mengidentifikasi kecenderungan individu mengalami emosi yang tidak menyenangkan spt: marah, cemas,stres, depresi; ide yang tidak realistis; coping yang tidak sesuai

2) Extraversion $(\mathrm{E})$ Mengukur kuantitas dan intensitas interaksi interpersonal, tingkat aktivitas, kapasitas untuk bahagia, emosi positif, kecenderungan untuk menjalin hubungan dengan orang lain.

3) Openness $(0)$
Mengukur penghargaan terhadap pengalaman sendiri, Menghargai seni, imajinatif, kreatif, menyadai perasaan sendiri,

4) Agreebleness (A)

Kecenderungan untuk merasa kasihan dan bekerja sama dibandingkan perasaan curiga dan permusuhan terhadap sesama

5) Conscientiousness (C)

Mengukur kecenderungan individu dalam mengontrol/mengatur dorongan;disiplin;pat uh;cenderung perilku terencana.

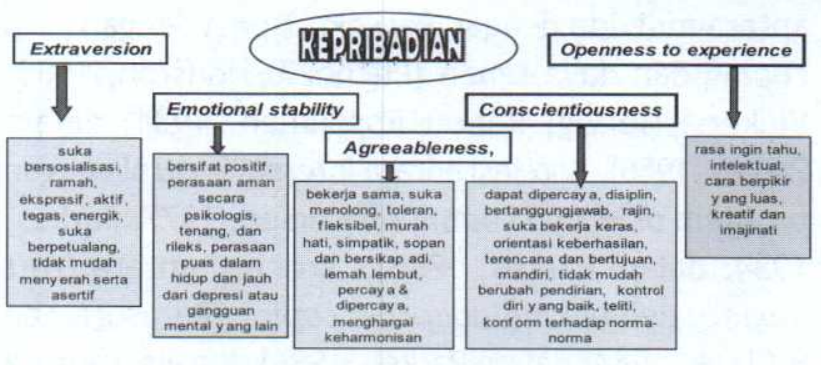

Gambar 1.2

Kecenderungan Kepribadian Menurut McCrae

\section{Strategi Coping}

Strategi coping menunjuk pada berbagai upaya, baik mental maupun perilaku, untuk menguasai, mentoleransi, mengurangi, atau minimalisasikan suatu situasi atau kejadian yang penuh tekanan. Dengan perkataan lain strategi coping merupakan suatu proses dimana individu berusaha untuk menanggani dan menguasai situasi stres yang menekan akibat dari masalah yang sedang dihadapinya dengan cara melakukan perubahan kognitif maupun perilaku guna memperoleh rasa aman dalam dirinya (Duhachek \& lacobucci, 2005). Lazarus daan Folkman, pada tahun 1984; ( Cohen \& Lazarus, 1983, Lazarus \& Folkmaan, 1984; sarafino, 1990; Taylor, 1995 ) menggambarkan coping sebagai : “.......Suatu proses di mana individu mencoba untuk mengelola jarak yang ada antara tuntutan-tuntutan ( baik itu tuntutan yang berasal dari individu maupun tuntutan yang berasal dari lingkungan ) dengan sumber - sumber daya yang mereka gunakan dalam mengatasi situasi stressful...".

Strategi coping yang biasanya digunakan oleh individu seringkali dikelompokkan menjadi dua, yaitu: problem-solving focused coping, dimana individu secara aktif mencari penyelesaian dari masalah untuk menghilangkan kondisi atau situasi yang menimbulkan stres; dan emotion-focused coping, dimana individu melibatkan usaha-usaha untuk mengatur emosinya dalam rangka menyesuaikan 
diri dengan dampak yang akan diitmbulkan oleh suatu kondisi atau situasi yang penuh tekanan. Hasil penelitian membuktikan bahwa individu menggunakan kedua cara tersebut untuk mengatasi berbagai masalah yang menekan dalam berbagai ruang lingkup kehidupan sehari-hari (Lazarus \& Folkman, 1984). Faktor yang menentukan strategi mana yang paling banyak atau sering digunakan sangat tergantung pada kepribadian seseorang dan sejauhmana tingkat stres dari suatu kondisi atau masalah yang dialaminya (Duhachek \& lacobucci, 2005). Contoh: seseorang cenderung menggunakan problem-solving focused coping dalam menghadapai masalah-masalah yang menurutnya bisa dikontrol seperti masalah yang berhubungan dengan sekolah atau pekerjaan; sebaliknya ia akan cenderung menggunakan strategi emotion-focused coping ketika dihadapkan pada masalah-masalah yang menurutnya sulit dikontrol seperti masalah-masalah yang berhubungan dengan penyakit yang tergolong berat seperti kanker atau Aids.

Pembagian dua macam strategi coping menjadi problem-solving focused coping dan emotion-focused coping merupakan hal yang penting. Beberapa peneliti menunjukkan bahwa respon-respon yang diberikan terhadap Ways of Scale menunjukkan lebih dari dua macam strategi tersebut ( Aldwin, Folkman, Schaefer, Coyne, \& Lazarus, 1980; Aldwin \& Revenson, 1987; Coyne, Aldwin, Lazarus, 1981; Folkman, Lazarus, 1985; Folkman, Lazarus, DunkelSchetter, DeLongis, \& Gruen, 1986; Parkes, 1984; Scheier, Weintraub, \& Carver, 1986, dalam Carver, Scheier \& Weintraub, 1989). Strategi-strategi coping tersebut antara lain seperti denial, positive reinterpretation, seeking social support; yang sering digolongkan kedalam emotion focused coping, dan strategi yang lain seperti planning, taking direction action, seeking assistance; yang digolongkan ke dalam problem focused coping. (Scheier dkk, 1986; dalam Carver, Scheier \& Weintraub, 1989), Hampir senada dengan penggolongan jenis coping seperti dikemukakan di atas, dalam literatur tentang coping juga dikenal dua strategi coping, yaitu active \& avoidant coping strategi (Lazarus mengkategorikan menjadi Direct Action \& Palliative). Active coping merupakan strategi yang dilakukan individu dengan cara menghadapi sumber stres, sementara avoidant coping merupakan strategi yang dilakukan individu untuk menjauhkan diri dari sumber stres dengan cara melakukan suatu aktivitas atau menarik diri dari suatu kegiatan atau situasi yang berpotensi menimbulkan stres. Active coping diasumsikan merupakan strategi yang lebih efektif dibandingkan dengan avoidant coping. Individu-individu yang mengunakan active coping lebih bisa keluar dari permasalahan yang dihadapi daripada individu yang memilih avoidant coping (Holahan \& Moos, 1987).

\section{Faktor-faktor yang Mempengaruhi Strategi Coping}

Ada beberapa faktor yang mempengaruhi strategi coping yaitu 1) faktor sosiodemografik, meliputi status sosial ekonomi, status perkawinan, status pekerjaan, gender, tingkat pendidikan; 2) faktor kepribadian, seperti kecenderungan neurotik, optimisme, locus of control, self esteem , kepercayaan diri dan lain sebagainya; 3 ) peristiwa hidup yang menekan, yaitu peristiwa yang dialami individu yang dirasa menekan dan mengancam kesejahteraan hidup seperti sakit, bencana, kehilangan milik yang berharga dan lain sebagainya dan 4) sumbersumber jaringan sosial, yang meliputi dukungan sosial (Holahan \& Moos, 1987).

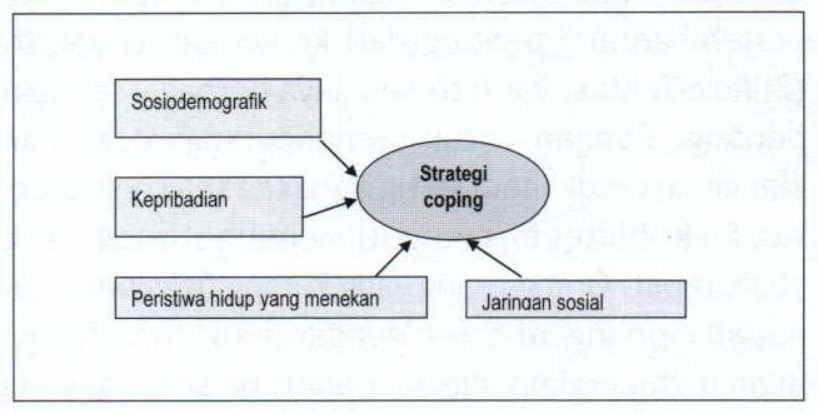

Gambar 1.3

Faktor-faktor yang mempengaruhi Strategi Coping

\section{Penilaian Kognitif dalam Strategi Coping}

Proses coping yang dilakukan individu selain tidak bisa lepas dari proses bagaimana penilaian orang terhadap hal, peristiwa, atau keadaan yang menimbulkan stres. Lazarus \& Folkman (1994) mengajukan suatu model stres yang menekankan adanya proses kognitif dalam proses pengelolaan stres. Pada saat menghadapi stressor, individu melakukan penilaian apakah stressor tersbeut mengancam dirinya atau tidak. Proses kognitif itu disebut sebagai primary appraisal. Kemudian individu akan menilai kemampuan dirinya dan apakah tersedia padanya sumber daya untuk menghadapi tuntutan itu. Proses Kognitif ini disebut sebagai secondary appraisal. Dengan melihat apakah sumber daya yang dimiliki cukup atau tidak untuk mengatasi kerugian, ancaman dan tantangan yang ada pada 
hal yang mendatangkan stres itu. Proses kognitif kemudian dilanjutkan dengan strategi coping yang pada akhirnya akan berdampak pada tinggi rendahnya stres yang dialami individu (Holahan \& Moos, 1987, Hardjana, 1994).

Penilaian peristiwa yang mendatangkan stres itu berpangkal dari tiga pemikiran. Pertama, penilaian tentang kerugian dan kehilangan (harmloss), kedua, pemikiran tentang ancaman (threat), ketiga pemikiran tentang tantangan (challenge). (Hardjana, 1994). Penilaian individu tentang hal, peristiwa, orang, atau keadaan yang menimbulkan stres dipengaruhi oleh dua hal yaitu faktor internal (pribadi) dan faktor eksternal (lingkungan). Faktor pribadi meliputi unsur intelektual, motivasi dan kepribadian. Berkaitan dengan kepribadian. Antonovsky (dalam Candra, 2001) mengemukakan bahwa setiap strategi penanggulangan stres mempunyai 3 komponen utama, yaitu (1) rasionalitas, yaitu suatu penilaian yang akurat, obyektif tentang situasi atau sumber stres. Penekanan kuat yang sudah diletakkan pada penilaian obyektif telah berakibat pada kecenderungan untuk melihat secara berlebihan arti penting dari kenyataan obyektif. (2) fleksibilitas, yaitu tersedianya berbagai strategi penanggulangan untuk menangulangi stres dan keinginan untuk mempertimbangkan semua strategi itu. Fleksibilitas ini meliputi memilih strategi yang paing tepat. Orang-orang yang kurang fleksibel tidak dapat menangani stres dengan baik, dan hanya ingin mempertimbangkan beberapa strategi yang terbatas, dan(3) daya pandang jauh ke depan, yaitu kemampuan untuk mengantisipasi konsekuensi dari berbagai strategi penanggulangan kita. Komponenkomponen ini saling berkaitan dan penanggulangan yang efektif memerlukan ketiga komponen tadi hingga taraf yang optimal.

\section{PEMBAHASAN}

Strategi coping merupakan suatu proses dimana individu berusaha untuk menanggani dan menguasai situasi stres yang menekan akibat dari masalah yang sedang dihadapinya dengan cara melakukan perubahan kognitif maupun perilaku guna memperoleh rasa aman dalam dirinya (Duhachek \& lacobucci, 2005). Proses coping yang dilakukan individu selain tidak bisa lepas dari proses bagaimana penilaian orang terhadap hal, peristiwa, atau keadaan yang menimbulkan stres.

Bagaimana proses penilaian orang terhadap hal, peristiwa, orang tua atau keadaan terjadi sehingga akhirnya sampai pada kesimpulan bahwa hal, peristiwa, orang atau keadaan itu sungguh menekan, menegangkan, penuh stres. Proses itu disebut penilaian kognitif (cognitive appraisal). Lewat proses itu, orang yang menghadapi hal, peristiwa, orang atau keadaan meniali apakah semuanya itu mengandung tuntutan yang mengancam kesejahteraannya dan apakah tersedia padanya sumber daya untuk menghadapi tuntutan itu. (Holahan \& Moos, 1987, Hardjana, 1994)

Pada waktu dihadapkan pada hal, peristiwa, orang atau keadaan yang dapat mengakibatkan stres individu memikirkan kemungkinan-kemungkinan yang dapat menimpa individu tersebut. Pertama, individu menyimpulkan bahwa hal yang mendatangkan stres itu tidak berarti apa-apa bagi kesejahteraan hidupnya. Kedua, individu sampai pada kesimpulan bahwa persitiwa yang dapat mendatangkan stres itu ternyata baik dan mendatangkan keuntungan bagi dirinya. Ketiga, individu mau tidak mau harus menerima bahwa keadaan yang dihadapi memang mendatangkan stres (Hardjana, 1994). Bersamaan dengan proses penilaian tersebut individu juga menilai dan mempertimbangkan sumber daya yang ada dalam dirinya untuk mengatasi stres. Dengan melihat apakah sumber daya yang dimiliki cukup atau tidak untuk mengatasi kerugian, ancaman dan tantangan yang ada pada hal yang mendatangkan stres itu. Sumber daya yang dimiliki dapat bersifat fisiologis, psikologis dan sosial. Hasil penilaian itu akan mempengaruhi berat ringannya stres yang dialami. Jika individu sampai pada kesimpulan bahwa hal yang mendatangkan stres dapat diatasi, maka stres ringan akan dialami, sebaliknya jika individu merasa tidak mampu menghadapi hal yang penuh stres, maka individu itu akan mengalami stres berat.

Penilaian individu tentang hal, peristiwa, orang, atau keadaan yang menimbulkan stres dipengaruhi oleh dua hal yaitu faktor internal (pribadi) dan faktor eksternal (lingkungan). Faktor pribadi meliputi unsur intelektual, motivasi dan kepribadian. (Hardjana, 1994). Orang yang berkepribadian neurotic cenderung melihat stres sebagai sesuatu yang negatif, dalam berhadapan dengan peristiwa stres individu tersebut melihatnya bukan sebagai tantangan tetapi sebagai ancaman dan individu tersebut mudah sampai pada kesimpulan bahwa dirinya tidak mampu mengatasi peristiwa stres yang dijumpai pada akhirnya orang berkepribadian neurotic lebih cenderung memilih strategi avoidant coping, dan cenderung tidak menggunakan problem focused coping (Guntherd, Armeli \& Cohen, 1999). Sebaliknya orang dengan 
kecenderungan kepribadian optimis akan melihat peristiwa yang menekan dengan cara yang positif. Orang yang optimis merasa mempunyai harapan dibalik semua peristiwa yang menimbulkan stres dan merasa yakin dengan sumber daya yang dimiliki, dan pada akhirnya orang dengan kecenderungan kepribadian yang optimis cenderung memilih strategi active coping atau problem focused coping ketika menghadapi peristiwa yang menimbulkan stres (Duhachek \& lacobucci, 2005). Orang yang mempunyai kecenderungan ekstrovert lebih sering memilih strategi coping yang adaptif, aktif dan sebaliknya orang yang introvert lebih memilih avoidant coping. (Posella, tt)

Namun perlu dicermati sekali lagi bahwa selain kepribadian ada beberapa faktor yang ikut mempengaruhi pemilihan strategi coping diantaranya adalah faktor jaringan sosial, seperti dukungan sosial. Hal ini sesuai dengan penelitian yang dilakukan oleh Holahan \& Moos (1987) yang menunjukkan bahwa strategi active coping cenderung dipilih oleh orang dengan kecenderungan kepribadian easy going yang ditunjang oleh dukungan sosial dari keluarga dan tingkat pendidikan yang tinggi. Rasionalisasi dari hal tersebut adalah ketika seseorang menilai bahwa suatu peristiwa yang dihadapi menimbulkan stres (primary appraisal), tetapi ketika merasa bahwa dirinya memiliki sumber daya yang dapat dipergunakan untuk mengelola stres tersebut (secondary appraisal) maka individu akan cenderung memberikan respon yang positif terhadap sumber stres tersebut.

Sehingga dapat disimpulkan bahwa faktor kepribadian akan mempengaruhi penilaian terhadap sumber stres (primary appraisal) yang selanjutnya akan berpengaruh terhadap penilaian tentang sumber daya yang dimiliki dalam rangka menghadapi sumber stres tersebut (secondary appraisal) seterusnya

\section{DAFTAR PUSTAKA}

1990. Coping as a Personaity Process: A Perspective Study. Journal of Personality and Social Psychology. 39. 3. 525.573.

Carver,Charles S. Scheier Michael F. \& Weintraub, Jagdish K. 1986. Coping With Stress: Divergent Strategies of Optimistis and Pessimists. Journal Personality and Social Psychology. 31.6. 12571264

Cosway. Richard, Endler. Norman S., Sandler. Andrew J. \& Deary. Ian J.2006. Relationship akan menentukan strategi coping apa yang akan dipilih. Sedangkan faktor sosiodemografik dan dukungan sosial akan mempengaruhi penilaian akan sumber daya yang dimiliki (secondary appraisal) selanjutnya akan mempengaruhi strategi coping yang akan dipilih.

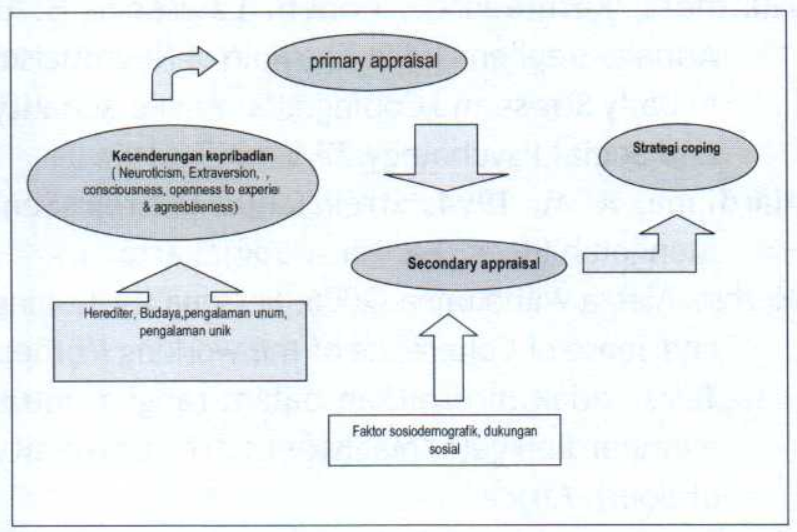

Gambar 1.4

Peran Kecenderungan Kepribadian Dalam Pemilihan Strategi

\section{KESIMPULAN}

Konsep utama dari peran kecenderungan kepribadian dalam pemilihan strategi dapat disimpulkan bahwa faktor kepribadian akan mempengaruhi penilaian terhadap sumber stres (primary appraisal) yang selanjutnya akan berpengaruh terhadap penilaian tentang sumber daya yang dimiliki dalam rangka menghadapi sumber stres tersebut (secondary appraisal) seterusnya akan menentukan strategi coping apa yang akan dipilih. Sedangkan faktor sosiodemografik dan dukungan sosial akan mempengaruhi penilaian akan sumber daya yang dimiliki (secondary appraisal) selanjutnya akan mempengaruhi strategi coping yang akan dipilih.

between Coping Strategies, Personality Traitas and Psychological Distress in Bam Earthquake Survivors. IJMS. 31.4.191-195.

Dilinger, Tracy G., Wiegmann. Douglas A \& Taneja, Narindra. 2003. Relating Personality with stress coping strategies among Student Pilots in a Collegiate Flifht Training Program. Disampingkan pada Symposium on Aviation Psyhology. Dayton.

Duhaceck, Adam., laobucci, Dawn. Consumer Personality and Coping Testing Rival Theories 
of Process. Journal of Consumer Psychology. 15.1. 52-63

Gohm, Carol. L., \& Clore, Gerald L. 2002. Four Laten traits of emotional experience and their involvement in well being, coping, abd attributional syle. Cognition and Emotion. 16.4. 495-518.

Gunthert, Kathleen C., Cohen, Lawrence H. \& Armeli, Stephen. 1999. The Role of Neuroticism in Daily Stress and Coping. Journal Personality and Social Psychology.77.5.1087-110.

Hardjana, A. M. 1994. Stres Tanpa Distres: Seni mengolah Stres. Kanisius. Jogjakarta.

Herbst. Aletta Wilhelmina. 2006. Personality, Coping and Sense of Coherence of the working Mother. Tesis. tidak diterbitkan dalam rangka untuk memperoleh gelar Magister of Art. University of South Africa.

Holahan, Charles. J \& Moos, Rudolf H. 1987. Personal and Contextual Determinant of Coping Strategies. Journal Personality and Social Psychology.52.5.946-955.
Kuntjoro, Z.S. 2002. Dukungan Sosial pada lansia. http//www.e-psikologi.com/usia/160802. htm.

Lindzey, G. \& Aronson, E. 1975. The Handbook of Social Psychology. New York: Addison Westly Publishing Company.

Posella, Daniella. Tt. Coping Style Used by Introverts in varying Stress Situation.

Scheie, r Michael F. \& Weintraub, Jagdish K. 1986. Coping With Stress: Divergent Strategies of Optimistis and Pessimists. Journal Personality and Social Psychology. 31.6. 1257-1264.

Smet, B. 1994. Psikologi Kesehatan. PT. Grasindo. Jakarta

Taylor, S.E, Peplau, Lt, Sears, D.O. 1997. Social Psychology. New Jersey. Prentice Hall.

Terry, Deborah. J. 1994. Determinants of Coping : The Role of Stable and Situational Factors. Journal Personality and Social Psychology.6.5.895910 